Research article

\title{
Nitrous oxide from moving bed based integrated fixed film activated sludge membrane bioreactors
}

\author{
Giorgio Mannina a , Marco Capodici ${ }^{\text {a, }}{ }^{\text {, }}$, Alida Cosenza a ${ }^{a}$, Daniele Di Trapani ${ }^{\text {a }}$, \\ Vito Armando Laudicina ${ }^{\mathrm{b}}$, Hallvard Ødegaard ${ }^{\mathrm{c}}$ \\ a Dipartimento di Ingegneria Civile, Ambientale, Aerospaziale, dei Materiali, Università di Palermo, Viale delle Scienze, Ed. 8, 90100, Palermo, Italy \\ b Dipartimento di Scienze Agrarie e Forestali, Università di Palermo, Viale delle Scienze, Ed. 4, 90128, Palermo, Italy \\ ${ }^{\mathrm{c}}$ Norwegian University of Science and Technology, Department of Hydraulic and Environmental Engineering, 7491 Trondheim, Norway
}

\section{A R T I C L E I N F O}

\section{Article history:}

Received 14 July 2016

Received in revised form

8 November 2016

Accepted 12 November 2016

\section{Keywords:}

Nitrous oxide

Emission factor

IFAS

MBR

UCT

\begin{abstract}
A B S T R A C T
The present paper reports the results of a nitrous oxide $\left(\mathrm{N}_{2} \mathrm{O}\right)$ production investigation in a moving bed based integrated fixed film activated sludge (IFAS) membrane bioreactor (MBR) pilot plant designed in accordance with the University of Cape Town layout for biological phosphorous removal. Gaseous and liquid samples were collected in order to measure the gaseous as well as the dissolved concentration of $\mathrm{N}_{2} \mathrm{O}$. Furthermore, the gas flow rate from each reactor was measured and the gas flux was estimated. The results confirmed that the anoxic reactor represents the main source of nitrous oxide production. A significant production of $\mathrm{N}_{2} \mathrm{O}$ was, however, also found in the anaerobic reactor, thus indicating a probable occurrence of the denitrifying phosphate accumulating organism activity. The highest $\mathrm{N}_{2} \mathrm{O}$ fluxes were emitted from the aerated reactors $\left(3.09 \mathrm{~g} \mathrm{~N}_{2} \mathrm{O}-\mathrm{N} \mathrm{m}^{-2} \mathrm{~h}^{-1}\right.$ and $9.87 \mathrm{~g} \mathrm{~N}_{2} \mathrm{O}-\mathrm{N} \mathrm{m}^{-2} \mathrm{~h}^{-1}$, aerobic and MBR tank, respectively). The emission factor highlighted that only $1 \%$ of the total treated nitrogen was emitted from the pilot plant. Furthermore, the measured $\mathrm{N}_{2} \mathrm{O}$ concentrations in the permeate flow were comparable with other reactors. Nitrous oxide mass balances outlined a moderate production also in the MBR reactor despite the low hydraulic retention time. On the other hand, the mass balance showed that in the aerobic reactor a constant consumption of nitrous oxide (up to almost $15 \mathrm{mg}$ $\mathrm{N}_{2} \mathrm{O} \mathrm{h}^{-1}$ ) took place, due to the high amount of stripped gas.
\end{abstract}

(C) 2016 Elsevier Ltd. All rights reserved.

\section{Introduction}

Nitrous oxide $\left(\mathrm{N}_{2} \mathrm{O}\right)$ is a significant greenhouse gas ( $\left.\mathrm{GHG}\right)$ due to its high global warming potential (GWP), 298 times higher than that of carbon dioxide $\left(\mathrm{CO}_{2}\right)$ (IPCC, 2007). In this context, $\mathrm{N}_{2} \mathrm{O}$ emissions from wastewater treatment has received increasing attention in recent years (Kampschreur et al., 2009; Law et al., 2012; Mannina et al., 2016a). Specifically, $\mathrm{N}_{2} \mathrm{O}$ generation mainly occurs in biological nitrogen removal (BNR) (Cosenza et al., 2013) via nitrification and denitrification processes as both autotrophic and heterotrophic bacteria can be responsible for $\mathrm{N}_{2} \mathrm{O}$ production during BNR (Kampschreur et al., 2009).

During nitrification, $\mathrm{N}_{2} \mathrm{O}$ may be produced by ammonia oxidizing bacteria (AOB) (Peng et al., 2014, 2015) originating via two main pathways (Kampschreur et al., 2009): (1) the reduction of

\footnotetext{
* Corresponding author.

E-mail address: marco.capodici@unipa.it (M. Capodici).
}

$\mathrm{NO}_{2}^{-}$as terminal electron acceptor to $\mathrm{N}_{2} \mathrm{O}$ (AOB denitrification) (Kim et al., 2010; Yu et al., 2010; Wrage et al., 2001; Stuven et al., 1992); (2) incomplete oxidation of hydroxylamine $\left(\mathrm{NH}_{2} \mathrm{OH}\right)$ to $\mathrm{NO}_{2}^{-}$(Law et al., 2012; Chandran et al., 2011).

$\mathrm{N}_{2} \mathrm{O}$ may, however, also be produced in incomplete heterotrophic denitrification, since it represents a process intermediate (Lu and Chandran, 2010; Pan et al., 2013; Liu et al., 2015).

In the last years, many efforts have been devoted towards the understanding of the key mechanisms involved in $\mathrm{N}_{2} \mathrm{O}$ production and emission (Kampschreur et al., 2009; Quan et al., 2012; Rodriguez-Caballero and Pijuan, 2013; Stenström et al., 2014; Wu et al., 2014; Hwang et al., 2016; Mannina et al., 2016c). The reported studies demonstrated a huge variability of the $\mathrm{N}_{2} \mathrm{O}$ emission (from the $0.01 \%$ to $10 \%$ of the influent total nitrogen) (Yoshida et al., 2014), depending on the WWTPs operational conditions (Kampschreur et al., 2009; Law et al., 2012; Daelman et al., 2013). Moreover, the technical literature shows that in processes aimed at the simultaneous nitrogen and phosphorous removal (SNPR), the role of 
polyphosphate accumulating organisms (PAOs) in the production of $\mathrm{N}_{2} \mathrm{O}$ cannot be disregarded (among others, Zhou et al., 2012).

In the last years, hybrid SNPR processes combining in the same reactor suspended and attached biomass (IFAS-system) have been proposed. IFAS systems can maximize nitrification thanks to the high retention time of the biofilm, while at the same time operating the suspended growth phase with short sludge retention time (SRT). Moreover, anoxic conditions in the inner biofilm layers may promote simultaneous nitrification and denitrification even in aerobic reactors (Leyva-Díaz et al., 2014). This aspect can be of importance with respect to $\mathrm{N}_{2} \mathrm{O}$ emissions from SNPR in hybrid systems. Very recently, the joint use of membrane bioreactors (MBRs) and moving bed biofilm reactors (MBBRs) in an IFAS-system was proposed (Di Trapani et al., 2014) for improving system performance and it is usually referred to as moving bed membrane bioreactor (MB-MBR) or IFAS-MBR.

Concerning $\mathrm{N}_{2} \mathrm{O}$ emissions, it has to be pointed out that most of the studies reported in the literature focuse on suspended biomass and a recent review paper by Todt and Dörsch (2016) proved that very little attention was paid to biofilm systems. Only a couple of studies have been carried so far (among others Lo et al., 2010; Ma et al., 2015; Todt and Dörsch, 2015), indicating that significant knowledge gaps still exist. As far as the present authors are aware of, no studies are available on $\mathrm{N}_{2} \mathrm{O}$ emission from IFAS system coupled to MBR and more knowledge is therefore needed. Sen et al. (2010) developed a model in order to investigate on the differences in GHG emission between integrated IFAS and conventional activated sludge (CAS). They indicated that in IFAS, due to the need for media mixing, the higher air supply may help in achieving complete nitrification, thus lowering the potential for GHG emissions. Therefore, there is a need to better understand the mechanisms involved on $\mathrm{N}_{2} \mathrm{O}$ production from hybrid systems aimed at nutrient removal.

The aim of the present study was, therefore, to characterize the $\mathrm{N}_{2} \mathrm{O}$ emissions from a University of Cape Town IFAS-MBR (UCTIFAS-MBR) pilot plant. In order to obtain accurate estimation of the emissions, a fully covered pilot plant was used to capture the overall $\mathrm{N}_{2} \mathrm{O}$ gas emissions and thus avoiding misevaluation related to measuring devices generally located in a small portion of the reactors. Further, the membrane was placed in a separate compartment in order to single-out the contribution of $\mathrm{N}_{2} \mathrm{O}$ emissions due to MBR aeration for fouling mitigation.

\section{Materials and methods}

\subsection{Pilot plant lay-out}

The lay-out of the UCT- IFAS-MBR pilot plant is shown in Fig. 1; it was operated for 51 days.

The anaerobic, anoxic and aerobic reactors (volume equal to $62 \mathrm{~L}, 102 \mathrm{~L}$ and $211 \mathrm{~L}$, respectively) were designed in accordance with UCT scheme. The inlet flux $\mathrm{Q}_{\mathrm{IN}}$ was set at $20 \mathrm{~L} \mathrm{~h}^{-1}$. The membrane module (PURON ${ }^{\circledR} 3$ bundle) was located in a $36 \mathrm{~L}$ reactor continuously aerated (MBR reactor). The ultrafiltration module yielded two fluxes: permeate flux ( $\mathrm{Q}$ out $=20 \mathrm{~L} \mathrm{~h}^{-1}$ ) and retentate flux $\left(Q_{\text {RAS }}=80 \mathrm{~L} \mathrm{~h}^{-1}\right)$. The former was collected in a clean in place unit (CIP) that stored the volume necessary to the periodical membrane backwashing (1 min every $9 \mathrm{~min}$ ), discharging the surplus by means of a weir. The retentate was recycled in an oxigen depletion reactor (ODR) and thus to the anoxic reactor. A flux equal to $20 \mathrm{~L} \mathrm{~h}^{-1}\left(\mathrm{Q}_{\mathrm{R} 1}\right)$ was continuously recycled from the anoxic to the anaerobic reactor while a $100 \mathrm{~L} \mathrm{~h}^{-1}$ flow $\left(\mathrm{Q}_{\mathrm{R} 2}\right)$ was conveyed from the aerobic to the MBR reactor. Furthermore, the anoxic and aerobic compartments were filled with suspended carriers (Amitech s.r.l.) with a 15 and $40 \%$ filling fraction respectively, corresponding to a net surface area of 75 and $205 \mathrm{~m}^{2} \mathrm{~m}^{-3}$, respectively.

Moreover, the anaerobic, anoxic, aerobic and MBR reactors were equipped with specific funnel shape covers that guaranteed gas accumulation in the headspace to perform the gas sampling.

\subsection{Operative conditions and experimental performances}

During the experimental campaign, the pilot plant was operated with no sludge withdrawal. As the core aim of the present paper deals with $\mathrm{N}_{2} \mathrm{O}$ production, only the mean values of the operational parameters are briefly summarized in Table 1 .

\subsection{Gas sampling and measurements}

Samples from liquid phase as well as head space were withdrawn from each reactor and analyzed to determine the $\mathrm{N}_{2} \mathrm{O}-\mathrm{N}$ concentration in accordance with Mannina et al. (2016b). Furthermore, nitrous oxide emission factor were assessed in accordance with Tsuneda et al. (2005) expressing the emitted nitrous oxide as a percentage of nitrogen fed to the pilot plant.

In order to evaluate the gas production or consumption inside each reactor, the nitrous oxide mass balance was calculated in accordance to Equation (1).

$\mathrm{N}_{2} \mathrm{O}-\mathrm{N}_{\mathrm{p}, \mathrm{c}}=\mathrm{N}_{2} \mathrm{O}-\mathrm{N}_{\text {Dissolved,OUT }}+\mathrm{N}_{2} \mathrm{O}-\mathrm{N}_{\text {Gas, OUT }}-$

$\mathrm{N}_{2} \mathrm{O}-\mathrm{N}_{\text {Dissolved,IN }}$

where: $\mathrm{N}_{2} \mathrm{O}-\mathrm{N}_{\text {Dissolved,IN }}$ [mg $\mathrm{N}_{2} \mathrm{O}-\mathrm{N} \mathrm{h}^{-1}$ ] and $\mathrm{N}_{2} \mathrm{O}-\mathrm{N}_{\text {Dissolved,OUT }}$ [mg $\mathrm{N}_{2} \mathrm{O}-\mathrm{N} \mathrm{h}^{-1}$ ] are fluxes of dissolved $\mathrm{N}_{2} \mathrm{O}-\mathrm{N}$, entering and exiting a reactor, respectively; $\mathrm{N}_{2} \mathrm{O}-\mathrm{N}_{\mathrm{Gas}, \mathrm{OUT}}\left[\mathrm{mg} \mathrm{N}_{2} \mathrm{O}-\mathrm{N} \mathrm{h}^{-1}\right]$ is the gaseous $\mathrm{N}_{2} \mathrm{O}-\mathrm{N}$ exiting a reactor; $\mathrm{N}_{2} \mathrm{O}-\mathrm{N}_{\mathrm{p}, \mathrm{c}}\left[\mathrm{mg} \mathrm{N}_{2} \mathrm{O}-\mathrm{N} \mathrm{h}^{-1}\right]$ is the flux of $\mathrm{N}_{2} \mathrm{O}-\mathrm{N}$ produced (if positive) or consumed (if negative) in the reactor.

\section{Results and discussion}

The gas phase concentrations are shown in Fig. 2. The $\mathrm{N}_{2} \mathrm{O}$ gas concentration remained close to constant during the experimental period excepting the anoxic reactor, where gas concentration showed significant fluctuations compared to the other reactors. On the 25th experimental day, the gas concentration in the anoxic reactor started to increase up to the maximum value of $210 \mu \mathrm{g}$ $\mathrm{N}_{2} \mathrm{O}-\mathrm{N} \mathrm{L}^{-1}$ that was recorded at day 32 . This result is likely due to incomplete denitrification occurring during these days, with nitrate concentration in the permeate flow ranging from 33.6 to $41 \mathrm{mg}$ $\mathrm{NO}_{3}-\mathrm{N} \mathrm{L}^{-1}$. This circumstance affected the gas production in the anoxic reactor, in agreement with literature data indicating that incomplete denitrification can lead to $\mathrm{N}_{2} \mathrm{O}$ production (Kampschreur et al., 2009). Several authors agree in identifying the anoxic reactor as the main source of $\mathrm{N}_{2} \mathrm{O}$ production (Otte et al., 1996; Kampschreur et al., 2009).

On average, the gas concentrations throughout experiments were equal to $15.40 \mu \mathrm{g} \mathrm{N}_{2} \mathrm{O}-\mathrm{N} \mathrm{L}^{-1}, 29.11 \mu \mathrm{g} \mathrm{N} \mathrm{N}_{2} \mathrm{O}-\mathrm{N} \mathrm{L}^{-1}, 13.97 \mu \mathrm{g}$ $\mathrm{N}_{2} \mathrm{O}-\mathrm{N} \mathrm{L}^{-1}$ and $12.50 \mu \mathrm{g} \mathrm{N} \mathrm{N}_{2} \mathrm{O}-\mathrm{N} \mathrm{L}^{-1}$ for anaerobic, anoxic, aerobic and MBR reactor, respectively.

Based on the measured gas concentration, the flux emitted from each reactor was assessed, as shown in Fig. 3.

The results reported in Fig. 3 highlight the effect of the air supply to the $\mathrm{N}_{2} \mathrm{O}$ emission as well as the effect of the carriers. The flux measured in the aerated reactors (Fig. 3a) was two orders of magnitude higher than the flux measured in the not aerated reactors (Fig. 3b). The air supplied to the aerobic reactor (to guarantee the aerobic environment) and to the MBR reactor (mainly for fouling mitigation) enhanced the physical stripping of the gas from the liquid phase. The average fluxes measured in each reactor were 


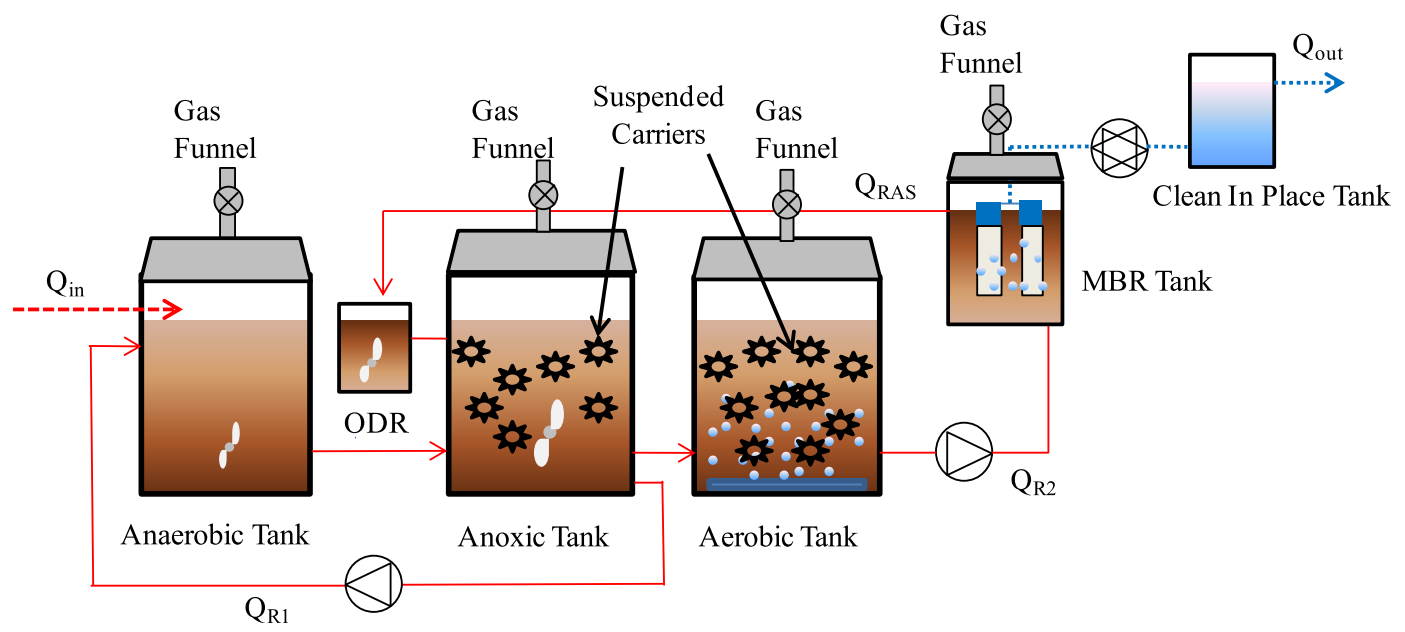

Fig. 1. Lay-out of the UCT - IFAS-MBR pilot plant.

Table 1

Mean values of operational parameters.

\begin{tabular}{|c|c|c|c|c|c|c|c|}
\hline $\mathrm{COD}_{\text {in }}\left[\mathrm{mg} \mathrm{L}^{-1}\right]$ & $\mathrm{TN}_{\mathrm{in}}\left[\mathrm{mg} \mathrm{L}^{-1}\right]$ & $\mathrm{PO}_{4}-\mathrm{P}_{\text {in }}\left[\mathrm{mg} \mathrm{L}^{-1}\right]$ & $\mathrm{TSS}_{\text {anaerobic }}\left[\mathrm{g} \mathrm{L}^{-1}\right]$ & $\mathrm{TSS}_{\text {anoxic }}\left[\mathrm{g} \mathrm{L}^{-1}\right]$ & $\mathrm{TSS}_{\text {aerobic }}\left[\mathrm{g} \mathrm{L}^{-1}\right]$ & $\mathrm{TSS}_{\mathrm{MBR}}\left[\mathrm{g} \mathrm{L}^{-1}\right]$ & VSS/TSS mean \\
\hline 577 & 60 & 9 & 1.96 & 3.83 & 3.97 & 4.75 & 0.86 \\
\hline
\end{tabular}

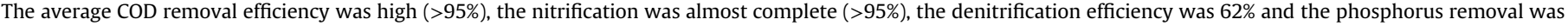
$25 \%$.

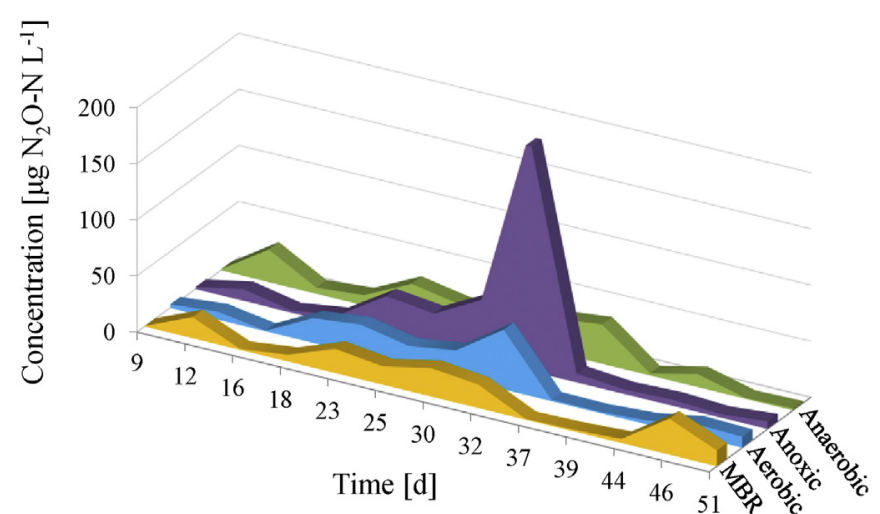

Fig. 2. Gas phase concentrations.

$25.39 \mu \mathrm{g} \mathrm{N}{ }_{2} \mathrm{O}-\mathrm{N} \mathrm{m}^{-2} \mathrm{~h}^{-1}, 25.01 \mu \mathrm{g} \mathrm{N} \mathrm{N}_{2} \mathrm{O}-\mathrm{N} \mathrm{m}^{-2} \mathrm{~h}^{-1}, 3092 \mu \mathrm{g}$ $\mathrm{N}_{2} \mathrm{O}-\mathrm{N} \mathrm{m}^{-2} \mathrm{~h}^{-1}$ and $9872 \mu \mathrm{g} \mathrm{N} \mathrm{N}_{2} \mathrm{O}-\mathrm{N} \mathrm{m}^{-2} \mathrm{~h}^{-1}$ for anaerobic, anoxic, aerobic and MBR reactor, respectively.

The $\mathrm{N}_{2} \mathrm{O}$ flux emitted from the MBR reactor was found to be three times higher than that of the aerobic reactor on average. This result is emphasized since the scientific literature consider the nitrogen transformation process as the main source of nitrous oxide (Kampschreur et al., 2009; Law et al., 2012; Zhao et al., 2014) while in the MBR reactor, due to the low HRT $(0.36 \mathrm{~h})$, very little biological activity is expected to occur. The presence in the aerobic reactor of both suspended and attached biomass probably enhanced the gas production thus contributing to the flux emission. The reason for the huge emission from the MBR reactor is likely due to the high $\mathrm{Q}_{\mathrm{R} 2}$ flow $\left(100 \mathrm{~L} \mathrm{~h}^{-1}\right)$ constantly pumped from the aerobic to the MBR reactor and thus recycling the dissolved nitrous oxide produced in the aerobic reactor. Dissolved $\mathrm{N}_{2} \mathrm{O}$ conveyed to the MBR reactor was stripped to the gaseous phase, due to the intensive aeration provided for membrane fouling mitigation and hence contributing to the large flux emitted from MBR.
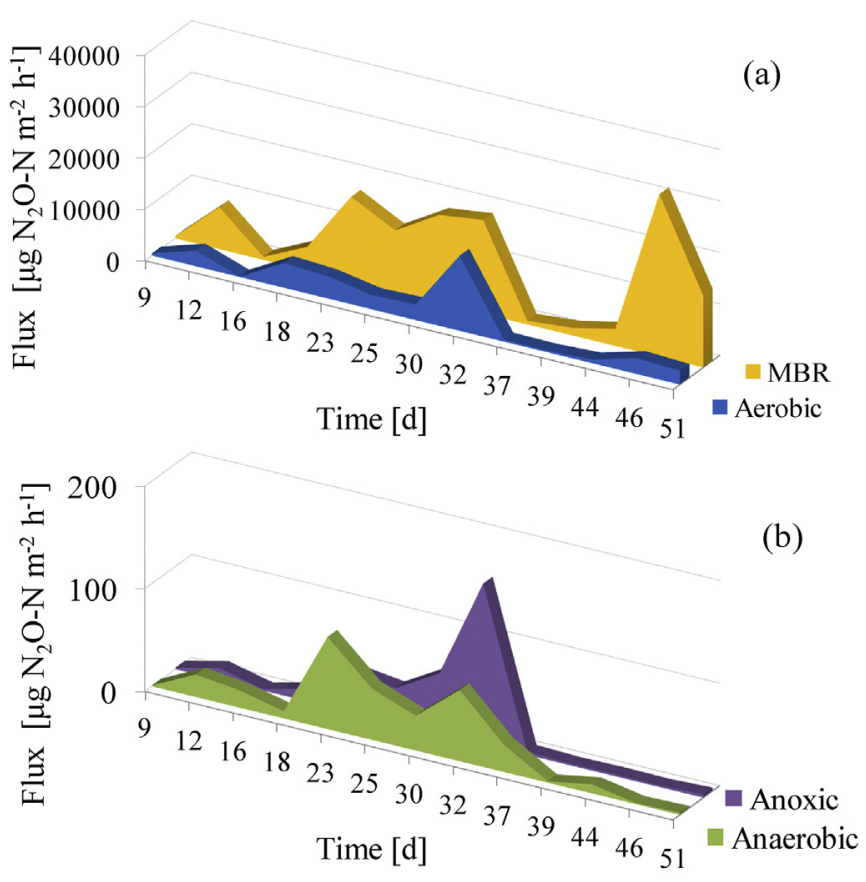

Fig. 3. $\mathrm{N}_{2} \mathrm{O}-\mathrm{N}$ Flux emitted from aerated reactors (a) and not aerated reactors (b).

This aspect is also noticeable from the dissolved gas concentrations measured in the reactors of the pilot plant (see Fig. 4).

The results reported in Fig. 4 showed an opposite situation for the dissolved phase as compared to the gas phase and the emitted flux of nitrous oxide. Due to the absence of air supply, the measured concentration in the non-aerated reactors (Fig. 4a) resulted in one order of magnitude higher values than that of the aerated reactors and the permeate flow (Fig. 4b). The average concentrations 
(a)

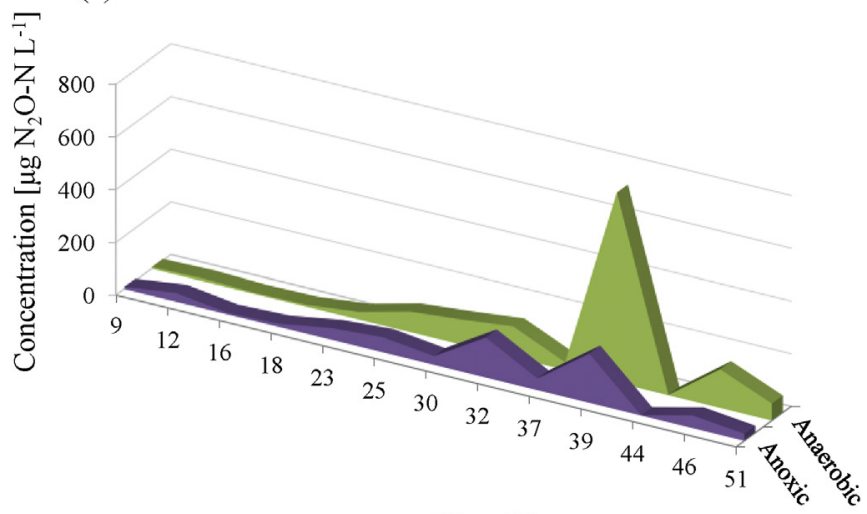

Time 「d]

(b)

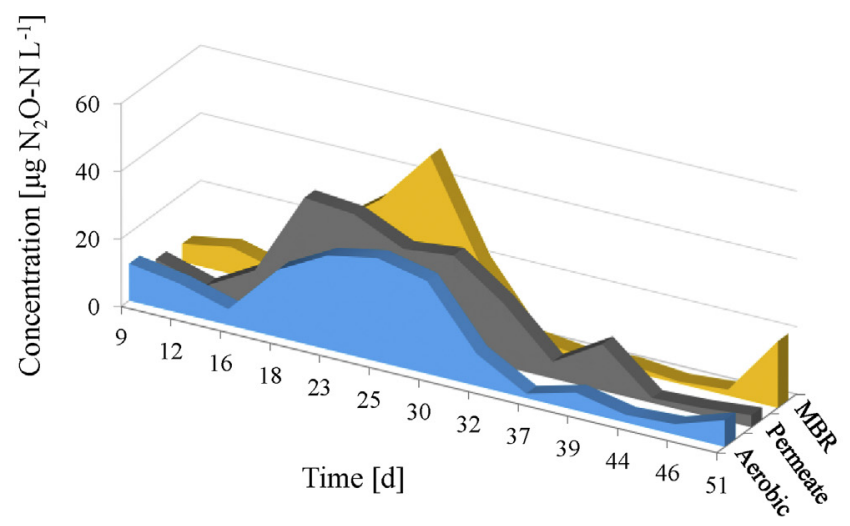

Fig. 4. Dissolved $\mathrm{N}_{2} \mathrm{O}-\mathrm{N}$ concentrations measured inside the anaerobic and anoxic reactors (a) and inside the aerobic and MBR reactors and in the permeate flow (b).

measured in each reactor and in the permeate flow were $100 \mu \mathrm{g}$ $\mathrm{N}_{2} \mathrm{O}-\mathrm{N} \mathrm{L}^{-1}, 50.30 \mu \mathrm{g} \mathrm{N} \mathrm{N}_{2} \mathrm{O}-\mathrm{N} \mathrm{L}^{-1}, 12.25 \mu \mathrm{g} \mathrm{N} \mathrm{N}_{2} \mathrm{O}-\mathrm{N} \mathrm{L}^{-1}, 13.12 \mu \mathrm{g}$ $\mathrm{N}_{2} \mathrm{O}-\mathrm{N} \mathrm{L}^{-1}$ and $14.63 \mu \mathrm{g} \mathrm{N} \mathrm{N}_{2} \mathrm{O}-\mathrm{N} \mathrm{L}^{-1}$ for the anaerobic, anoxic, aerobic and MBR reactor and for the permeate flow respectively. The circumstance that the highest dissolved concentration were achieved in the anaerobic reactor may be caused by anoxic conditions in the reactor whereby the denitrifying phosphate accumulating organisms (DPAOs) would use organic matter to denitrify instead of accumulating phosphate. This lead to a low biological phosphorus removal efficiency achieved during experiments $(25 \%$ on average). Several studies reported that $\mathrm{N}_{2} \mathrm{O}$ rather than $\mathrm{N}_{2}$ was the major denitrification product when DPAOs used poly- $\beta$ hydroxyalkanoates (PHA) as a carbon source for denitrification during denitrifying $P$ removal process (Lemaire et al., 2006; Jia et al., 2012; Wang et al., 2015). In this context, $\mathrm{N}_{2} \mathrm{O}$ production can be expected to be significantly influenced, since the synthesis of anaerobic PHA is significantly affected by the influent quality variation. Therefore, $\mathrm{N}_{2} \mathrm{O}$ production during denitrifying $\mathrm{P}$ removal could also be significant (Wang et al., 2015; Liu et al., 2015).

Concerning the anoxic reactor, the measured $\mathrm{N}_{2} \mathrm{O}$ concentration was consistent with previous studies that identified the anoxic reactor as one of the major contributors to $\mathrm{N}_{2} \mathrm{O}-\mathrm{N}$ production (Otte et al., 1996; Kampschreur et al., 2009; Liu et al., 2015).

In contrast, the results reported in Fig. $4 \mathrm{~b}$ confirm that the stripping effect exerted by the air supply on the aerobic and MBR reactor is very important with respect to the flux of $\mathrm{N}_{2} \mathrm{O}-\mathrm{N}$ emitted. The permeate flow concentration were comparable to dissolved concentrations measured in the other aerated reactor and thus not negligible.

In order to properly quantify the influence exerted by each reactor on the $\mathrm{N}_{2} \mathrm{O}$ emission, the emission factors have been assessed and the results are shown in Fig. 5.

The results reported in Fig. 5 indicate that the emission factors of each compartment, expressed as the percentage of the total nitrogen loading rate to the plant, varied moderately during the experiments, with a maximum value close to $1 \%$.

This result is consistent with previous studies carried out with similar systems. Todt and Dörsch (2015) found an emission factor ranging between $0.7 \%$ and $8.5 \%$ in a pure MBBR system; Kong et al. (2013) reported a mean emission factor equal to $2.7 \%$ in an MBBR operated with intermittent aeration; Lo et al. (2010) found an emission factor equal to $21 \%$ of nitrogen load in an IFAS system operated with intermittent aeration. However, Fig. 5a demonstrates that the main contributors of $\mathrm{N}_{2} \mathrm{O}$ emission were the aerated reactors while the contribution of the anaerobic reactor as well as of the anoxic reactor was negligible. This result is confirmed by data reported in Fig. 5b where the average contribution of each reactor is depicted. The MBR contribution represented on average $76.1 \%$ of the total emission, the aerobic reactor contributed on average with $21.4 \%$ of the total, while the sum of anaerobic and anoxic reactors contributed with a total of $2.5 \%$. This result is consistent with the results reported in Figs. 3 and 4, demonstrating that a significant fraction of $\mathrm{N}_{2} \mathrm{O}$ produced in the reactors without air supply is further conveyed and thereafter stripped in the aerated reactors.

As denitrification is considered to be one of the dominant factor in $\mathrm{N}_{2} \mathrm{O}$ production, the influence exerted by nitrate concentration in the nitrous oxide production is reported in Fig. 6 .

The data shown in Fig. 6 confirm the key role of the anoxic reactor in the $\mathrm{N}_{2} \mathrm{O}$ production. Indeed, the nitrate concentration in the anoxic reactor significantly influences the gas concentration as well as the flux (Fig. 6a and b). As the nitrate concentration increase, both gas concentration and gas flux increase logarithmic. Furthermore the $\mathrm{N}_{2} \mathrm{O}$ gaseous concentration in the anoxic reactor is strongly related to the nitrate concentration in the permeate flow (Fig. 6 c).

Nitrous oxide represents an intermediate product of denitrification and thus of incomplete denitrification (Kampschreur et al., 2009). Furthermore, in the anoxic reactor the dissolved nitrate should be removed, and if biological denitrification takes place, limited $\mathrm{N}_{2} \mathrm{O}$ production should result. The logical link between the latter observation and the presence of nitrate in the effluent is the accordance with the relation between gas concentration in the anoxic reactor and nitrate concentration in the effluent. Indeed the occurrence of high $\mathrm{N}_{2} \mathrm{O}$ production in the anoxic reactor should represent a limitation of the denitrification phenomenon thus leading to the presence of nitrates in the effluent flow rate. No nitrite accumulation occurred during the experimental campaign.

In order to investigate on the specific production/consumption of each reactor, the $\mathrm{N}_{2} \mathrm{O}$ mass balance analysis over the reactors was carried out and shown in Fig. 7.

The data presented in Fig. 7 a,b,c,d,e are consistent with the results previously discussed. Indeed, the mass balance highlights that in the anaerobic and anoxic reactor a net $\mathrm{N}_{2} \mathrm{O}$ production took place during the experimentation. This is in agreement with the higher $\mathrm{N}_{2} \mathrm{O}$ dissolved concentration measured in the non-aerated reactors. On the contrary, in the aerobic reactor the mass balance outlined a constant consumption of nitrous oxide (up to almost $15 \mathrm{mg} \mathrm{N}_{2} \mathrm{O} \mathrm{h}^{-1}$ ), due to the high amount of gas stripped. In the MBR reactor a clear trend of the mass balance result was not noticeable. This confirms that the high nitrous oxide flux emitted from the MBR reactor was due to a physical stripping of the gas produced in other reactors of the pilot plant and conveyed in the MBR with the $\mathrm{Q}_{\mathrm{R} 2}$. 

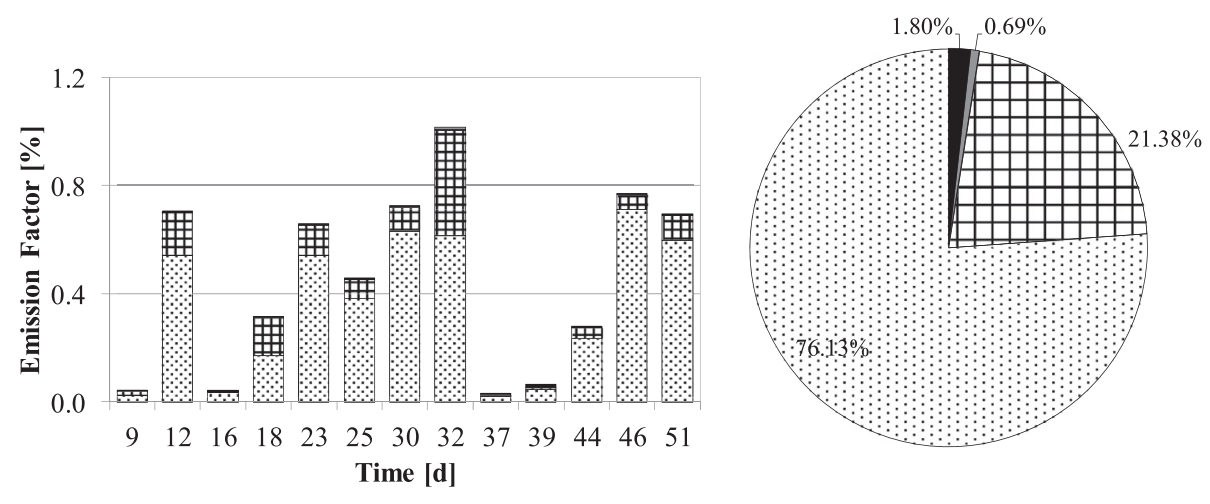

$\square$ ANOXIC ANAEROBIC вAEROBIC MBR

Fig. 5. $\mathrm{N}_{2} \mathrm{O}-\mathrm{N}$ emission factors (a) and average percentage contribution of each tank (b).
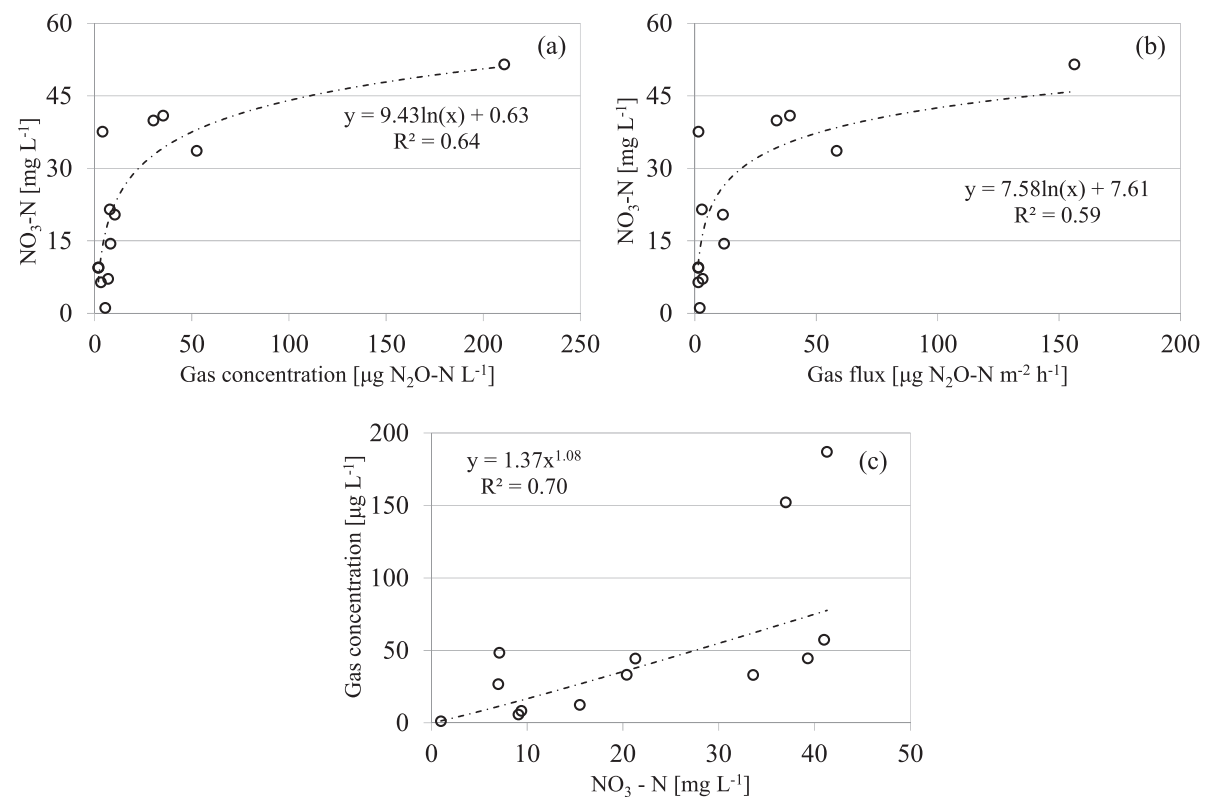

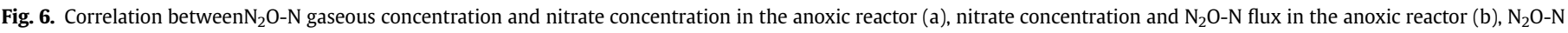
gaseous concentration in the anoxic reactor and nitrate concentration in the permeate flow (c).

The mass balance demonstrated, however, that the anaerobic and anoxic reactors represent the main source of $\mathrm{N}_{2} \mathrm{O}$ production ( $85 \%$ of the overall production) (Fig. $7 f$ ). Therefore, the results achieved in the present study indicate that the main pathway involved in the nitrous oxide production results from the heterotrophic denitrification, that normally occurs in the anoxic reactor, and the denitrifying $P$ removal process, that is promoted by DPAOs, in the anaerobic reactor.

\section{Conclusions}

This paper reports the results of experiments carried out in a MBBR-based IFAS MBR pilot plant operated according to the UCT design.

The final goal was to provide the first estimation of $\mathrm{N}_{2} \mathrm{O}$ emissions from pilot plants designed for carbon and nutrient removal with MBR. Further, the contribution for the production and stripping effect due to air supply was evaluated suggesting insights in MBR operation.
These results indicate that the anaerobic and the anoxic reactors represent the main source of nitrous oxide production. The physical effect of aeration that caused $\mathrm{N}_{2} \mathrm{O}$ stripping was noticed in the aerobic as well as in the MBR reactor. The $\mathrm{N}_{2} \mathrm{O}$ flux emitted from the aerated reactors was up to two orders of magnitude higher than that of not aerated (anaerobic and anoxic) reactors. Furthermore, due to the absence of the aeration, the concentration of $\mathrm{N}_{2} \mathrm{O}$ in the non-aerated reactors was an order of magnitude higher than the concentration in the aerated reactors and permeate flow. The $\mathrm{N}_{2} \mathrm{O}$ concentration measured in the permeate flow was comparable to the concentrations measured in the aerobic and MBR reactors and thus not negligible. The emission factor assessment showed that only around $1 \%$ of the influent nitrogen was emitted as $\mathrm{N}_{2} \mathrm{O}$ from the whole pilot plant.

By taking into account the biological parameters of the pilot plant, the nitrate concentration within the anoxic reactor turned out to be a key factor in the influence of the $\mathrm{N}_{2} \mathrm{O}$ production. The experiments demonstrated that further studies are required in order to better understand the influence of the operational 
(a)

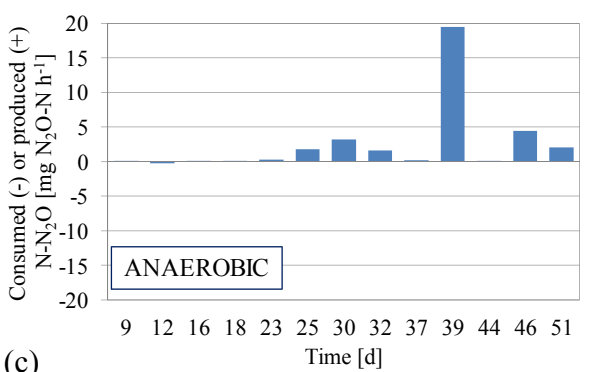

(c)

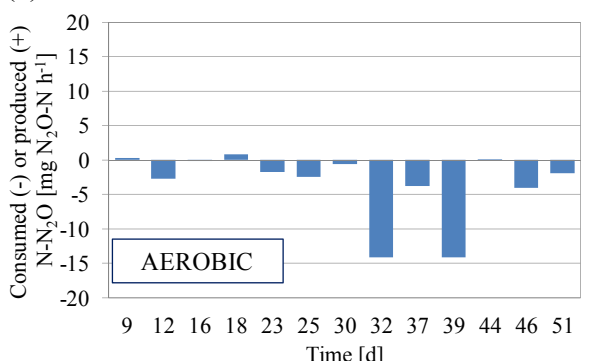

(e)

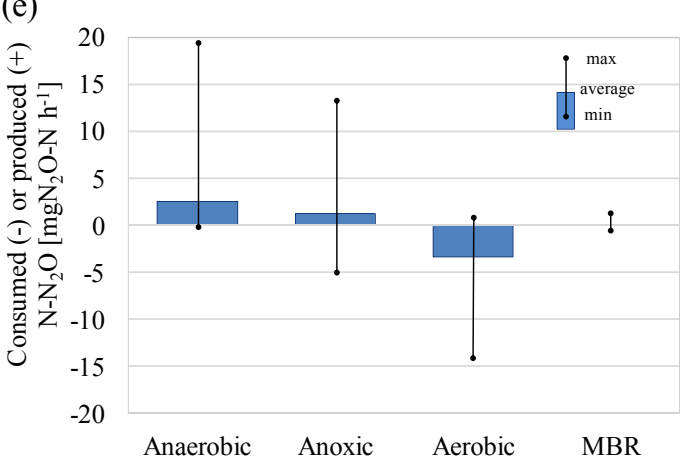

(b)
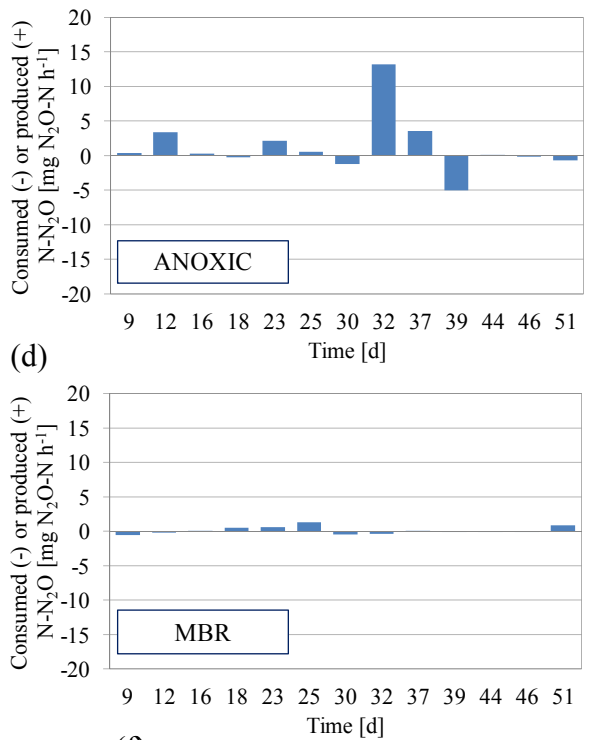

(f)

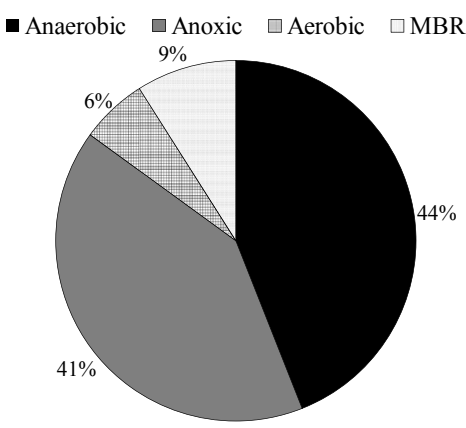

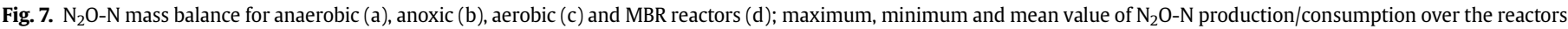
(e); mean percentage of $\mathrm{N}_{2} \mathrm{O}-\mathrm{N}$ production over the reactors (f).

parameters, as well as the biomass features, on $\mathrm{N}_{2} \mathrm{O}$ production. Indeed, in the reported experiments a net specific contribution of the attached or suspended biomass was not noticeable.

\section{Acknowledgements}

This work forms part of a research project supported by grant of the Italian Ministry of Education, University and Research (MIUR) through the Research project of national interest PRIN2012 (D.M. 28 dicembre 2012 n. 957/Ric - Prot. 2012PTZAMC) entitled “Energy consumption and GreenHouse Gas (GHG) emissions in the wastewater treatment plants: a decision support system for planning and management - http://ghgfromwwtp.unipa.it" in which the first author of this paper is the Principal Investigator. Authors warmly thank Amitec srl for providing the suspended carriers and Koch Membrane Systems Inc. for providing the membrane module.

\section{References}

Chandran, K., Stein, L.Y., Klotz, M.G., van Loosdrecht, M.C.M., 2011. Nitrous oxide production by lithotrophic ammonia oxidizing bacteria and implications for engineered nitrogen-removal systems. Biochem. Soc. Trans. 39, 1832-1837.

Cosenza, A., Di Bella, G., Mannina, G., Torregrossa, M., Viviani, G., 2013. Biological nutrient removal and fouling phenomena in a University of Cape Town membrane bioreactor treating high nitrogen loads. J. Environ. Eng. 139, 773-780.

Daelman, M.R.J., De Baets, B., Volcke, E.I.P., van Loosdrecht, M.C.M., 2013. Influence of sampling strategies on the estimated nitrous oxide emission from wastewater treatment plants. Water Res. 47, 3120-3130.
Di Trapani, D., Di Bella, G., Mannina, G., Torregrossa, M., Viviani, G., 2014. Comparison between moving bed-membrane bioreactor (MB-MBR) and membrane bioreactor (MBR) systems: influence of wastewater salinity variation. Bioresour. Technol. 162, 60-69.

Hwang, H.L., Bang, C.H., Zoh, K.D., 2016. Characteristics of methane and nitrous oxide emissions from the wastewater treatment plant. Short Commun. Bioresour. Technol. http://dx.doi.org/10.1016/j.biortech.2016.05.047.

IPCC, 2007. Changes in atmospheric constituents and in radiative forcing. In: Solomon, S., et al. (Eds.), Climate Change 2007: The Physical Science Basis. Contribution of Working Group I to the Fourth Assessment Report of the Intergovernmental Panel on Climate Change. Cambridge University Press, Cambridge, pp. 114-143.

Jia, W.L., Zhang, J., Xie, H.J., Yan, Y.J., Wang, J.H., Zhao, Y.X., Xu, X.L., 2012. Effect of $\mathrm{PHB}$ and oxygen uptake rate on nitrous oxide emission during simultaneous nitrification denitrification process. Bioresour. Technol. 113, 232-238.

Kampschreur, M.J., Temmink, H., Kleerebezem, R., Jetten, M.S.M., van Loosdrecht, M.C.M., 2009. Nitrous oxide emission during wastewater treatment. Water Res. 43, 4093-4103.

Kim, S.W., Miyahara, M., Fushinobu, S., Wakagi, T., Shoun, H., 2010. Nitrous oxide emission from nitrifying activated sludge dependent on denitrification by ammonia oxidizing bacteria. Bioresour. Technol. 101, 3958-3963.

Kong, Q, Zhang J., Miao, M. Tian, L. Guo, N., Liang, S., 2013. Partial nitrification and nitrous oxide emission in an intermittently aerated sequencing batch biofilm reactor. Chem. Eng. J. 217, 435-441.

Law, Y., Ni, B.J., Lant, P., Yuan, Z., 2012. $\mathrm{N}_{2} \mathrm{O}$ production rate of an enriched ammonia-oxidising bacteria culture exponentially correlates to its ammonia oxidation rate. Water Res. 46, 3409-3419.

Lemaire, R., Meyer, R., Taske, A., Crocetti, G.R., Keller, J., Yuan, Z.G., 2006. Identifying causes for $\mathrm{N}_{2} \mathrm{O}$ accumulation in a lab-scale sequencing batch reactor performing simultaneous nitrification, denitrification and phosphorus removal. J. Biotechnol. 122, 62-72.

Leyva-Diaz, J.C., Martín-Pascual, J., Munío, M.M., González-López, J., Hontoria, E. Poyatos, J.M., 2014. Comparative kinetics of hybrid and pure moving bed reactor-membrane bioreactors. Ecol. Eng. 70 (2014), 227-234. 
Liu, Y., Peng, L., Chen, X., Ni, B.-J., 2015. Mathematical modeling of nitrous oxide production during denitrifying phosphorus removal process. Environ. Sci. Technol. 49, 8595-8601.

Lo, I.W., Lo, K.W., Mavinic, D.S., Shiskowski, D., Ramey, W., 2010. Contributions of biofilm and suspended sludge to nitrogen transformation and nitrous oxide emission in hybrid sequencing batch system. J. Environ. Sci. 22 (7), 953-960.

Lu, H., Chandran, K., 2010. Factors promoting emissions of nitrous oxide and nitric oxide from denitrifying sequencing batch reactors operated with methanol and ethanol as electron donors. Biotechnol. Bioeng. 106 (3), 390-398.

Ma, Y., Sundar, S., Park, H., Chandran, K., 2015. The effect of inorganic carbon on microbial interactions in a biofilm nitritation-anammox culture. Water Res. 70 , 246-254.

Mannina, G., Ekama, G, Caniani, D., Cosenza, A., Esposito, G., Gori, R., GarridoBaserba, M., Rosso, D., Olsson, G., 2016a. Greenhouse gases from wastewater treatment - a review of modelling tools. Sci. Total Environ. 551-552, 254-270.

Mannina, G. Morici, C. Cosenza, A Di Trapani, D Ødegaard, H., 2016b Greenhouse gases from sequential batch membrane bioreactor: a pilot plant case study. Biochem. Eng. J. 112, 114-122.

Mannina, G., Cosenza, A., Di Trapani, D., Laudicina, V.A., Morici, C., Ødegaard, H. 2016c. Nitrous oxide emissions in a membrane bioreactor treating saline wastewater contaminated by hydrocarbons. Bioresour. Technol. 219, 289-297. http://dx.doi.org/10.1016/j.biortech.2016.07.124.

Otte, S., Grobben, N.G., Robertson, L.A., Jetten, M.S.M., Kuenen, J.G., 1996. Nitrous oxide production by Alcaligenes faecalis under transient and dynamic aerobic and anaerobic conditions. Appl. Environ. Microbiol. 62 (7), 2421-2426.

Pan, Y., Ni, B.J., Yuan, Z., 2013. Modeling electron competition among nitrogen oxides reduction and $\mathrm{N}_{2} \mathrm{O}$ accumulation in denitrification. Environ. Sci. Technol. 47 (19), 11083-11091.

Peng, L.B.-J., Ni Ye, L., Yuan, Z., 2015. The combined effect of dissolved oxygen and nitrite on $\mathrm{N}_{2} \mathrm{O}$ production by ammonia oxidizing bacteria in an enriched nitrifying sludge. Water Res. 73, 29-36.

Peng, L., Ni, B.-J., Erler, D., Ye, L., Yuan, Z., 2014. The effect of dissolved oxygen on $\mathrm{N}_{2} \mathrm{O}$ production by ammonia-oxidizing bacteria in an enriched nitrifying sludge. Water Res. 66, 12-21.

Quan, X., Zhang, M., Lawlor, P.G., Yang, Z., Zhan, X., 2012. Nitrous oxide emission and nutrient removal in aerobic granular sludge sequencing batch reactors. Water Res. 46, 4981-4990.

Rodriguez-Caballero, A., Pijuan, M., 2013. $\mathrm{N}_{2} \mathrm{O}$ and NO emissions from a partial nitrification sequencing batch reactor: exploring dynamics, sources and minimization mechanisms. Water Res. 47, 3131-3140.
Sen, D., Lodhi, A., Copithorn, R., Randall, C.W., Pehrson, R., Chandran, K., 2010 Differences in GHG emission between IFAS and Activated Sludge - developing a fast and accurate computational model - AQUIFAS + - to simulate media, mixing and aeration, design and operation of plants. In: WEF/IWA Biofilm Reacto Technology Conference 2010.

Stenström, F., Tjus, K. la Cour Jansen, J., 2014. Oxygen-induced dynamics of nitrous oxide in water and off-gas during the treatment of digester supernatant. Water Sci. Technol. 69, 84-91.

Stuven, R., Vollmer, M., Bock, E., 1992. The impact of organic matter on nitric oxide formation by Nitrosomonas europaea. Archives Microbiol. 158 (6), 439-443.

Todt, D., Dörsch, P., 2015. Nitrous oxide emissions in a biofilm loaded with different mixtures of concentrated household wastewater. Int. J. Environ. Sci. Technol. 12 (11), 3405-3416

Todt, D., Dörsch, P., 2016. Mechanism leading to $\mathrm{N}_{2} \mathrm{O}$ production in wastewater treating biofilm systems. Rev. Environ. Sci. Biotechnol. 15 (3), 355-378.

Tsuneda, S., Mikami, M., Kimochi, Y., 2005. Effect of salinity on nitrous oxide emission in the biological nitrogen removal process for industrial wastewater. J. Hazard Mater. 119, 93-98.

Wang, Z., Meng, Y., Fan, T., Du, Y., Tang, J., Fan, S., 2015. Phosphorus removal and $\mathrm{N}_{2} \mathrm{O}$ production in anaerobic/anoxic denitrifying phosphorus removal process: longterm impact of influent phosphorus concentration. Bioresour. Technol. 179 585-594.

Wrage, N., Velthof, G.L., van Beusichem, M.L., Oenema, O., 2001. Role of nitrifie denitrification in the production of nitrous oxide. Soil Biol. Biochem. 33 (12-13), 1723-1732.

Wu, G., Zheng, D., Xing, L., 2014. Nitritation and $\mathrm{N}_{2} \mathrm{O}$ emission in a denitrification and nitrification two-sludge system treating high ammonium containing wastewater. Water 6, 2978-2992.

Yoshida, H., Mønster, J., Scheutz, C., 2014. Plant-integrated measurement of greenhouse gas emissions from a municipal wastewater treatment plant. Water Res. 61, 108-118.

Yu, R., Kampschreur, M.J., Loosdrecht, M.C.M., Chandran, K., 2010. Mechanisms and specific directionality of autotrophic nitrous oxide and nitric oxide generation during transient anoxia. Environ. Sci. Technol. 44, 1313-1319.

Zhao, W., Wang, Y., Lin, X., Zhou, D., Pan, M., Yang, J., 2014. Identification of the salinity effect on $\mathrm{N}_{2} \mathrm{O}$ production pathway during nitrification: using stepwise inhibition and 15N isotope labeling methods. Chem. Eng. J. 253, 418-426.

Zhou, Y., Lim, M., Harjono, S., Ng, W.J., 2012. Nitrous oxide emission by denitrifying phosphorus removal culture using polyhydroxyalkanoates as carbon source. J. Environ. Sci. 24, 1616-1623. 